\title{
Cultural Heritage Viability: An Example of Traditional Transport in Central Europe
}

\author{
Aleš Smrčka
}

\author{
Mgr. Aleš Smrčka, PhD \\ Czech Academy of Sciences \\ Institute of Ethnology \\ Department of Critical Heritage Studies \\ Na Florenci 3 \\ 11000 Prague 1 \\ Czech Republic \\ e-mail: smrcka@eu.cas.cz \\ ORCID: 0000-0002-7279-8053
}

Mureológia a kultúrne dedičstvo, 2021, 9:2:27-44
DOI: $10.46284 / \mathrm{mkd} .2021 .9 .2 .2$

\section{Cultural Heritage Viability: An Example of Traditional Transport in Central Europe}

This paper focuses on traditional transport as a form of cultural heritage in Central Europe, looking at the modes of transport that are still viable today as a part of people's lives and livelihoods, as well as strategies to ensure their survival. The importance of preserving the original purpose of traditional transport modes, as well as their acquisition of new functions in the modern era, are examined in the context of the sustainability and viability of cultural heritage. The article also highlights crucial role of promoting the visibility of cultural phenomena to the public in encouraging their protection and ongoing sustainability. It also draws attention to some less positive examples of how forms of traditional transport are currently presented, examining approaches that may lead to the alteration of traditions and the construction of distorted images of cultural heritage. In the conclusion, I propose distinguishing between forms of traditional transport that continue to maintain people's livelihoods or generate entertainment, and forms which are merely reconstructions of traditional phenomena, intended only as imitations to recall the past.

Keywords: cultural heritage viability; traditional transport; intangible cultural heritage (ICH); UNESCO; Central Europe

\section{Introduction}

On an international level, there have been extensive and thematically diverse discussions on the viability and sustainability of cultural heritage. ${ }^{1}$ The specific issue of the viability of traditional transport has, however, yet to appear in these discussions. Nevertheless, the topic of transport heritage viability is a topical one, as evidenced by the fact that elements of traditional transport are included in many Central European countries' Representative Lists of Intangible Cultural Heritage $(\mathrm{ICH}) .^{2}$

\footnotetext{
${ }^{1}$ KIM, Soojung, WHITFORD Michelle M. and ARCODIA, Charles V. Development of intangible cultural heritage as a sustainable tourism resource: the intangible cultural heritage. In: Journal of Heritage Tourism, 14(5-6), 2019, pp. 422-435; PHILLIPS, Dan. Archeology, Conservation and Enhancement. The Role of Viability in the UK Planning System. In: Historic Environment: Policy and Practice, 10(3-4), 2019, pp. 345-362.

${ }^{2}$ Czechia: Timber-Rafting Tradition on the Vltava River (2017); Slovakia: Mountain Carrying (2018), Husbandry of Lipizzaner Horses at Topol'čianky (2017); Poland: Rafting traditions in Ulanów (2014); Germany: Timber Rafting (2014); Austria: Knowledge of Lipizzaner breeding (2016), Knowledge of Timber Rafting on the Upper Drau (2014); Hungary: Lipizzaner Horse Breeding in Hungary (2018); Slovenia: The making of pletna boats and using them on Lake Bled (2019), Cable ferrying (2016), Making drevak boats (2015).
} 
European ethnologists began to take an interest in traditional transport mainly in the second half of the twentieth century. Examples include Olaf Bockhorn in Austria; ${ }^{3}$ Józef Gajek and Zygmunt Kłodnicki in Poland; ${ }^{4}$ Ludvík Baran ${ }^{5}$ and Magdalena Paríková ${ }^{6}$ in Czechoslovakia; and Attila Paládi-Kovács in Hungary. ${ }^{7}$ In 1973, a multiauthor work on Land Transport in Europe was published. ${ }^{8}$ The interest in this topic persists today among contemporary ethnologists, including Katarína Slobodová Nováková ${ }^{9}$ and Peter Slavkovský ${ }^{10}$ in Slovakia; Aleš Smrčka and Daniel Drápala in Czechia; ${ }^{11}$ and Anna Drożdż in Poland. ${ }^{12}$ However, the research outputs of these authors mainly focus on historical discourse.

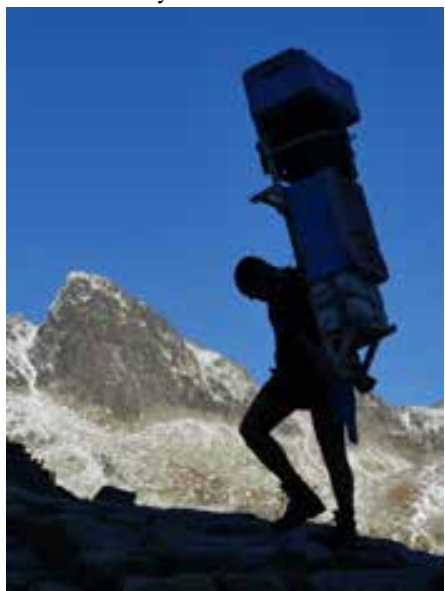

Fig. 1: A mountain porter carrying goods in the High Tatras in 2016.

Photo: Pavol Barabáš, with the author's permission.

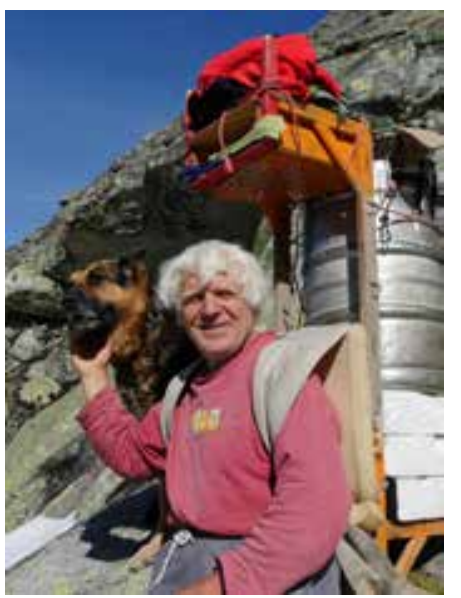

Fig. 2: A mountain porter and cottager. Photo: Pavol Barabáš, with the author's permission.

\footnotetext{
${ }^{3}$ BOCKHORN, Olaf. Bänerliche Fahræ̨enge aus dem Müblviertel. Linz: OÖ. Musealverein - Gesellschaft für Landeskunde, 1988.

${ }^{4}$ GAJEK, Józef (ed.). Kwestionariusz nr. 5: Transport i komunikacjalqdowa. Wrocław: PTL, 1960; KLODNICKI, Zygmunt. Reliktowe formy transportu nasobnego i recznego w kulturach ludowych środkowej Europy. Praca doktorska. Wrocław, 1976.

${ }^{5}$ BARAN, Ludvík. Transport in Czechoslovakia as an Ethnographical and Social Phenomenon. In: FENTON, Alexander, PODOLÁK, Ján and RASMUSSEN, Holger (eds). Land Transport in Europe. Copenhagen: Nationalmuseet, 1973, pp. 57-89.

${ }^{6}$ PARÍKOVÁ, Magdaléna. Návod na etnografický výskum transportu a dopravy. Bratislava: Slovenská národopisná spoločnost'pri SAV, 1979.

${ }^{7}$ PALÁDI-KOVÁCS, Attila: Einige Bemerkungen über die Traggeräte der ungarischen Bauernschaft. In: SZABADFALVI, József and UJVÁRY, Zoltán (eds). Studia Ethnographica et Folkloristica in honorem Béla Gunda. Müveltségés Hagyomány XIII-XIV. Debrecen: Kossuth Lajos Tudományegyetem, 1971, pp. 409-426.

${ }^{8}$ FENTON, Alexander, PODOLÁK, Ján and RASMUSSEN, Holger (eds). Land Transport in Europe. Copenhagen: Nationalmuseet, 1973.

${ }^{9}$ NOVÁKOVÁ, Katarína S. Nosenie na hlave ako archaický spôsob transportu nákladov v európskom priestore. In: Národopisný véstnike, 79(1), 2020, pp. 43-66.

${ }^{10}$ SLAVKOVSKÝ, Peter. S nošou za industrializáciou krajiny. Tradičné podoby dopravy na slovenskom vidieku. Bratislava: VEDA and Ústav etnológie Slovenskej akadémie vied, 2014.

${ }^{11}$ DRÁPALA, Daniel: Doprava. In: BROUČEK, Stanislav and JEǨÁBEK, Richard (eds). Lidová kultura. Národopisná encyklopedie Čech, Moravy a Slezskea. 2. svazek. Praha: Mladá fronta, 2007, pp. 449-451; SMRČKA, Aleš. Etnografický výzkum tradiční dopravy v českých a slovenských zemích - historie, současný stav a perspektivy. In: Slovensky narodopis-Slovak Ethnology, 65(1), 2017, 7-25.

${ }^{12}$ DROŻDŻ, Anna. Transport i komunikacja lądowa w materiałach źródłowych i publikacjach Polskiego Atlasu Etnograficznego - stan obecny i nowe perspektywy. In: Národopisný véstník , 77(1), 2018, pp. 5-24.
} 
Therefore, I would like to extend the discussion of traditional transport to explore the issue of its current viability. The aim is to acquaint ethnologists and museologists with the various forms of traditional transport that can currently be encountered in the field and, at the same time, draw attention to the issue of their viability and protection. The conclusions regarding the viability of cultural heritage with regard to traditional transport and the issues around its protection are based, apart from literature, on data collected during my long-term field research conducted between 2009-2020. During the course of my research - which involved observations and interviews conducted mainly in Czechia, Slovakia and Poland - I encountered various forms of transport that still exist in their original form and serve their original function, as well as some that exist in a changed form and are used in new cultural-social contexts.

\section{Forms of transport heritage viability \\ Unchanged form}

Traditional transport has been preserved in Central Europe in various forms and is still used, with variations in intensity and frequency, to this day. ${ }^{13}$ In the observed area, one of the unchanged forms is the traditional manner of transporting goods using mountain porters (Fig. 1, Fig. 2), which was added in 2019 to the Representative List of the Intangible Cultural Heritage of Slovakia. ${ }^{14}$ The continuity of mountain portering has been maintained until the present day thanks to the year-round need to supply high-altitude huts with goods. ${ }^{15}$ The profession is unique not only due to the preservation of its original traditional form - that is, the transportation of goods in a frame backpack - but also due to its rarity on the European continent. In Europe, the mountain porter profession is, at present, only associated with the cultural space of the Low and High Tatras and the Great Fatra mountain range in Slovakia. The reason for this is simple: cottages in these areas are located high in the mountains and are difficult to access. No infrastructure exists to allow access by car, therefore the only option is to go on foot. Alternative means of transportation, by helicopter, for instance, are simply too expensive. ${ }^{16}$

In addition to their traditional duties as goods suppliers, porters participate in an official race called the Sherpa Rally, which was established in 1985. Participants compete in ascent speed and carrying heavy cargo, while tourists spectate and cheer. ${ }^{17}$ Although this kind of event can be considered folklorism (a term explored in more detail below), it demonstrates that cultural heritage need not represent a completely unaltered cultural entity. On the contrary, some authors argue for the importance of innovation in the sustainability of cultural heritage and indicate the importance of cultural elements being open to change in order to retain their

\footnotetext{
${ }^{13}$ Cultural heritage in an unchanged form is defined according to its originality and authenticity as heritage consisting entirely of genuine cultural elements. If an objective approach is applied to evaluating authenticity, it would be defined as the genuine, unstaged presentation of heritage; NING, Wang. Rethinking authenticity in tourism experience. In: Annals of Tourism Research, 26(2), 1999, pp. 349-370; LOVRENTJEV, Sonja. Intangible Cultural Heritage and Tourism. In: Mediterranean Journal of Social Sciences, 6 (5S1), 2015, p. 523.

${ }^{14} \mathrm{ICH}$ lists - Mountain Carrying, accessed February 5, 2020, available at www.ludovakultura.sk/en/list-ich/mountain-carrying

${ }^{15}$ NOVAKOVA, Katarina and TURINICOVA, Zuzana. Sherpas in High Tatras as a Touristic Phenomenon (Analysis of a specific Alpine Profession as a European attraction). In: Internetional Conference on Economics, Education and Humanities (ICEEH'14), Bali: International Center of Economics, Humanities \& Management, 2014, p. 193.

${ }^{16}$ NOVAKOVA and TURINICOVA, Sherpas in..., p. 193.

${ }^{17}$ NOVÁKOVÁ, Katarína. Tatranski nosiči. Tatranská Lomnica: I\&B, 2008, pp. 90-93.
} 
significance. ${ }^{18}$ From this perspective, these portering competitions offer a means to maintain the generational knowledge transfer of this centuries-old tradition and ensure its viability.

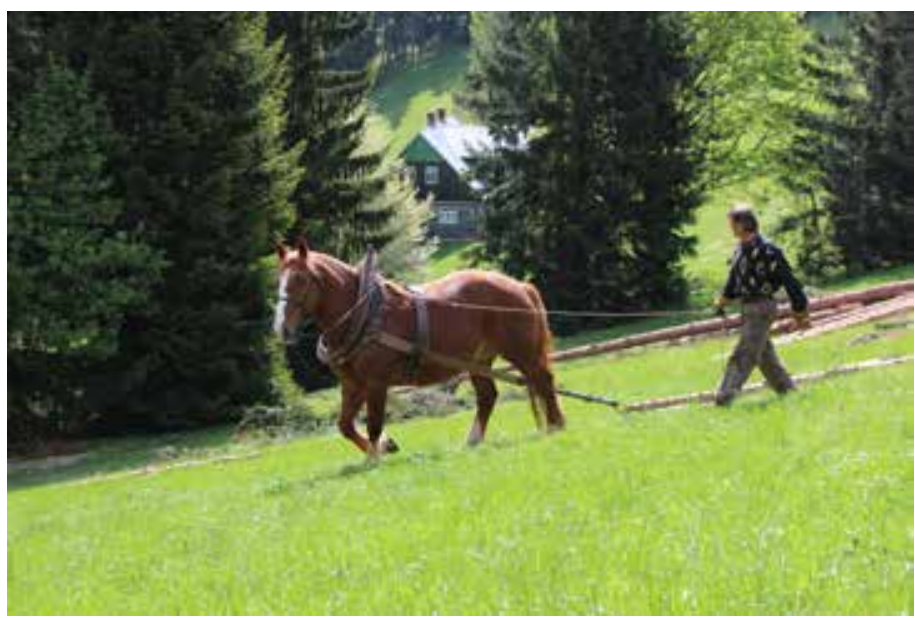

Fig. 3: A horse hauling wood in the Krkonose mountain range in 2012. Photo: author.

Another unchanged form of traditional transport in Central Europe is horse logging (Fig.3), a practice which is unique due to its constancy. The specifics of this mode of transportation have remained unchanged except for minor innovations such as adjustments in the work regime $^{19}$ - for centuries, as has the method of transferring knowledge to the next generation. Most forestry coachmen learn the basics of their profession by observing and gaining experience from older coachmen and pursue the profession because it is already followed in the family. I observed the present form of cultural transmission - which illustrates the practice's viability - while conducting field research in the Czech mountains. During a structured interview, a coachman mentioned that he was bringing his eight-year-old grandson to the forest and that the child would be helping by giving commands to the horse. ${ }^{20}$

The transportation of timber by horses is not limited to specific areas, but can be found in most mountainous areas of Czechia, Slovakia and other Central Europen countries. ${ }^{21}$ The reasons for its preservation today are pragmatic: horses are often the only means of moving logs in challenging mountain terrains where access is difficult. It is also an environmentally friendly form of transport, which is perceived positively by visitors to the forests. ${ }^{22}$

Regarding the future sustainability of this form of traditional transport, the greatest obstacle, in my view, may be insufficient visibility. At a local level, a number of projects are re-introducing or maintaining horse-based transport in forestry. However, coachmen do not act in an organised manner, nor do they form larger associations to coordinate their activities. The extent to which coachmen identify with their profession is subjective and questionable, as is the definition of a coachman's work as cultural heritage, as defined by Article 2 of the 2003 UNESCO Convention. Some coachmen do regard their profession as their ancestors' legacy, and as something that needs to be sustained and passed on. ${ }^{23}$ Many, however, do their job

\footnotetext{
${ }^{18}$ CHAN, Clare S. C. Sustainability of indigenous folk tales, music and cultural heritage through innovation. In: Journal of Cultural Heritage Management and Sustainable Development, 8(3), 2018, pp. 342-361.

${ }^{19}$ Interview with K. H. (b. 1953), coachman, December 17, 2017.

${ }^{20}$ Interview with J. B. (b. 1948), coachman, August 23, 2013.

${ }^{21}$ FICSOR, Csilla and MALATINSZKY, Ákos. A lovas közelítés, mint természetkímélő anyagmozgatási módszer helyzete a hazai erdőterületeken. In: Journal of Landscape Ecology, 12(1), 2014, pp. 127-135.

${ }^{22}$ KADLEC, Jiří and MATYSOVÁ, Zlata. Heavy Horses in City Forests of Ostrava. In: FIALOVÁ, Jitka and PERNICOVÁ, Dana (eds). Public recreation and landscape protection - with man hand in hand! 2015 Conference Proceeding. Brno: Czech Society of Landscape Engineers and Department of Landscape Management of Faculty of Forestry and Wood Technology of Mendel University in Brno, 2015, p. 88.

${ }^{23}$ Interview with J. G. (1957), coachman, November 5, 2019.
} 
simply as a means to earn money and make no reference to cultural heritage or seek to train successors to carry on the tradition. ${ }^{24}$

I've always been one to promote honour, but there's no honour in this craft. I said so even to the younger guys. But the young ones won't keep it up. Just a few of them. [...] They have horses, but they mostly work with tractors and they end up using the horses for just two months of the year. They prefer tractors. ${ }^{25}$

The situation observed in the Czech Republic and Slovakia is similar across Central Europe, and possibly even further afield. For example, in Hungary, as Csilla Ficsor and Ákos Malatinszky claim, only few people have the knowledge and are willing to work with horses, since the job requires significant adjustments to one's personal life. ${ }^{26}$ If technology continues to advance and the need to use horses to transport timber ceases to exist, this form of traditional transport will probably be lost. Moreover, the profession of coachman is not listed for protection in Central Europe.

Horse breeding presents a different case. In Slovakia, specifically in the Vel'ká lúka na Muráni area, horses have been bred specifically for forestry purposes since the 1950s. In 1997, they were declared a protected breed. ${ }^{27}$ Breeding non-draught horses is conducted in a similar manner. For example, the Lipizzaner is a breed registered on the Representative List of the Intangible Cultural Heritage of Slovakia, ${ }^{28}$ on the List of Intangible Cultural Heritage in Austria: Customs, knowledge, craft techniques, ${ }^{29}$ and on the List of Elements on the National Inventory of ICH in Hungary. ${ }^{30}$

Other forms of heritage transport, such as transporting materials on a wheelbarrow or in a textile sheet, face similar challenges with regard to their future sustainability. Textile sheets are occasionally used by individuals to transport hay from one place to another in activities associated with 'mountain chalet farming, ${ }^{31}$ which is typical in the Krkonoše Mountains ${ }^{32}$ and the Austrian Alps. ${ }^{33}$ Recently, however, there has been a boom in Europe in the use of textile

\footnotetext{
${ }^{24}$ Interview with P. J. (1960), coachman, July 12, 2018.

${ }^{25}$ Interview with J. G. (1957), coachman, November 5, 2019.

${ }^{26}$ FICSOR and MALATINSZKY, A lovas közelítés..., p. 135.

${ }^{27}$ ŠMELKO, Vladimír. História a súčasnost chovu norika muránského typu v š. p. LESY SR. In: STEINOVÁ, Šárka (ed.). Z historie lesního dopravnictví. Praha: Národní zemědělské muzeum, Banská Bystrica: LESY Slovenskej republiky š. p., Zvolen: Lesnícke a drevárske muzeum Zvolen, 2012, pp. 198-199.

${ }^{28}$ VOL'ANSKÁ, Lubica (ed.). Reprezentativny zoznam nebmotného kultúrneho dedičstva Slovenska, Zoznam nejlepšich spôsobov ochrany nebmotného kultúrneho dedičstva na Slovensku. Bratislava: Ministerstvo kultury Slovenskej republiky - SLUK Centrum pre tradičnú l'udovú kultúru, 2018, pp. 40-41; DOVČ, Peter, KAVAR, Tatjana, SÖLKNER, Hans and ACHMANN, Roland. Development of the Lipizzan horse breed. In: Reproduction in Domestic Animals, 41(4), 2006, pp. 280-285.

${ }^{29}$ Immaterielles Kulturerbe: Bräuche, Wissen, Handwerkstechniken - Wissen um die Lipizzanerzucht, accessed February 6, 2020, https://www.unesco.at/kultur/immaterielles-kulturerbe/oesterreichisches-verzeichnis/detail/ article/wissen-um-die-lipizzanerzucht/

${ }^{30}$ Intangible Cultural Heritage in Hungary - Lipizzaner horse breeding in Hungary, accessed February $6^{\text {st }}, 2020$, http://szellemikulturalisorokseg.hu/index0_en.php?name=en_0_lipica

${ }^{31}$ The phenomenon of mountain chalet farming refers to permanently (year-round) inhabited mountain dwellings with small farms. The owners would typically keep a goat and a cow, primarily for milk. Livestock were grazed in meadows or above the upper forest line, while the land around the dwelling, known as a grass garden, was fertilized regularly and used only to produce hay, to build up enough supplies for the winter to feed the livestock. The highlanders made butter, cottage cheese and cheese, and transported these dairy products down to the valley to sell. ${ }^{32}$ SMRČKA, Aleš. Die Bedeutung des Heus und sein traditioneller Transport im Riesengebirge. In: Cesky lid, 101(1), 2014, pp. 92-93.

${ }^{33}$ LECHNER, Eva and HÖLZL, Reinhard. Tiroler Almen. Innsbruck: Loewenzahn, 2008.
} 
sheets for carrying babies, ${ }^{34}$ an example demonstrating the transfer of a traditional means of transport from its original context to modern households. Again, the functionality of the phenomenon plays an essential role in preserving selected elements of cultural heritage.

\section{Folklorism}

Traditional transport in the region of Central Europe can also be found in the form of folklorism ${ }^{35}$ - where traditional culture is presented and/or revived in the form of folk performances or scientific reconstructions. ${ }^{36}$ Water transport in the Czech Republic represents one such phenomenon, specifically, log floating in the Sumava canals and timber rafting on the Vltava River, both of which are now carried out purely for the benefit of spectators, and not as a genuine means of transport relied upon by the local populace.

. In Slovakia, folklorism is also encountered in water transport in the form of commercial water rides for tourists on special rafts, called pltè, on the rivers Dunajec, Váh, Orava and Hron. Tourists who ride on pltě rafts for a fee learn about the toponyms of navigation routes, the history and traditions of rafting, the lives of former rafters, and the cultural-historical context of the surroundings. The transformation of the former Czechoslovakia's traditional methods of water transport into their current folklorism form dates to around the 1960s, when the experimental reconstruction of rafting practices was conducted in order to document the tradition. This was followed by demonstration raft rides for tourists in the twenty-first century. ${ }^{37}$ Similar demonstrations of raft navigation are also offered in Austria (Drau River),

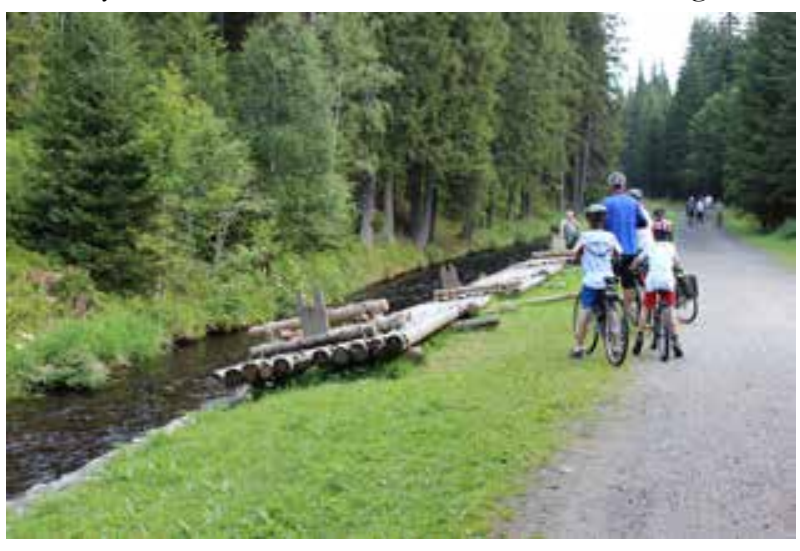

Fig. 4: A false presentation of raft navigation on the V chynice-Tetov Canal in the Sumava mountain range. Captured in 2014. Photo: author.
Germany (Lake Oberpfuhlsee, Finow Canal, Muldenberg Reservoir, and the Kronach, Rodach, Saale, Werra, Loisach, Isar, Nagold and Kinzig rivers), Poland (San, Wisl'a and Dunajec rivers) and Slovenia (Drau and Sava rivers).

The commercial exploitation of intangible cultural heritage or tradition cannot be completely condemned, since heritage also fulfils an economic function and supports tourism. ${ }^{38}$ Many debates within the scientific community are attempting to determine to what extent commodification affects the

\footnotetext{
${ }^{34}$ NOVÁKOVÁ, Katarína. Tradičné spôsoby prepravy detí v Európe a podoby ich súčasnej revitalizácie. In: Ethnologia Europea Centralis, 10, 2011, pp. 55-64.

${ }^{35}$ The use of the term "folklorism" is preferred to "revival of tradition" and "revitalizing traditions". The reason is that many changed phenomena of traditional transport continuously follow on the forms of the original likeness or function. Thus, the existence of the phenomenon has not been interrupted.

${ }^{36}$ ISTENIČ, Saša P. Texts and contexts of foklore. In: Traditiones, 40(3), 2011, p. 51.

${ }^{37}$ SLABA, Martin. Splavení posledního vltavského voru - př́běh jedinečného muzejního experimentu z roku 1971. In: STEINOVÁ, Šárka (ed.). Z bistorie lesníbo dopravnictví. Praha: Národní zemědělské muzeum, Banská Bystrica: LESY Slovenskej republiky š. p., Zvolen: Lesnícke a drevárske muzeum Zvolen, 2012, pp. 171-179.

${ }^{38}$ PETRONELA, Tudorache. The importance of the intangible cultural heritage in the economy. In: Procedia Economics and Finance, 39, 2016, pp. 731-736; Heritagisation can also be found in the food industry; PETROVA, Ivanka. Traditional culture and contemporary economy: Constructing cultural heritage through bread-making. In: Folklore (Estonia), 71, 2018, pp. 73-88.
} 
sustainability of cultural heritage. Some argue that the viability of cultural heritage can only be maintained if it is economically viable for the community. ${ }^{39}$ This can be applied not only to cultural phenomena maintained in the form of folklorism, but also to unchanged forms of traditional transport which do not benefit from tourism. The economic function still has a fundamental impact on their existence. However, the additional processes of commodification and touristification, as some authors mention, pose the risk of adversely altering the authenticity of cultural heritage. ${ }^{40}$ This is also an issue in the case of traditional transport. The problem arises when a cultural element is presented as an unchanged tradition or is linked to the wrong location by practitioners of the tradition in an effort to present cultural heritage to the public and increase its visibility. Thus, folklore becomes 'fakelore', defined as a fake tradition or false folklore that is presented as authentic. ${ }^{41}$

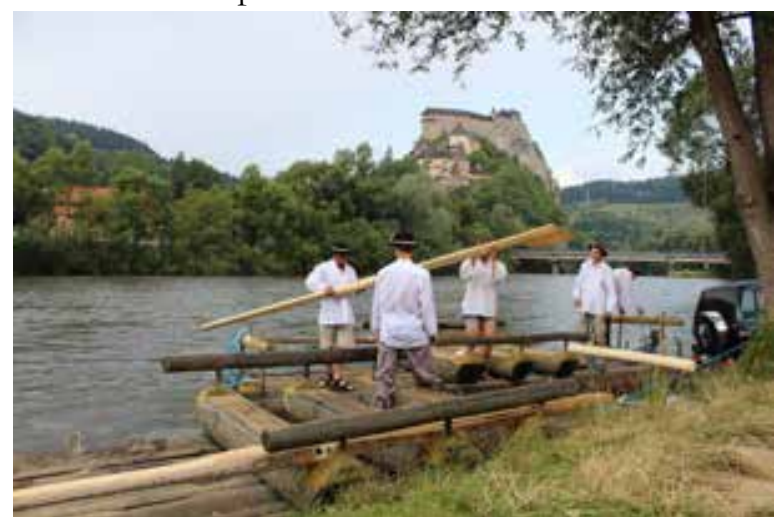

Fig. 5: Preparing plte rafts for tourist rides on the Orava River in Slovakia. 2015. Photo: author.

This phenomenon can be encountered in the Czech Republic in the mountains of Sumava, where tourists are shown the binding of raft boards and the subsequent navigation of the Vchynice-Tetov Canal (Fig.4). In the past, the Vchynice-Tetov and Schwarzenberg Canals were only used to float unbound logs. ${ }^{42}$ In Český Krumlov, southern Bohemia, one can observe sightseers riding on rafts, presented to them as traditional timber rafting, even though the vessels have nothing to do with the original rafts. ${ }^{43} \mathrm{~A}$ somewhat distorted image of cultural heritage is also created by the Slovakian pltě raft rides for tourists. If one compares the appearance of the modern plte rafts to the originals, considerable differences in their construction can be observed, largely due to the change in their purpose, which is now to facilitate sightseeing rides for tourists. In the case of the vessels on the Orava River, the differences in construction are minor (Fig. 5); the main difference is that modern plte rafts are constructed of tightly bound logs. The rafts used for tourist rides on the Dunajec River, on the other hand, are significantly different. Although it is logical that their different purpose should be reflected in an altered appearance, this fact must be considered when the cultural phenomenon is presented to the lay public, in order to avoid creating confusion and or generating a false image of cultural heritage.

The importance of preservating traditional water transport today is highlighted by the fact that the timber-rafting tradition on the Vltava River is the only form of traditional transport

\footnotetext{
${ }^{39}$ OLALERE, Folasyo E. Intangible cultural heritage as tourism product: The Malaysia experience. In: African Journal of Hospitality, Tourism and Leisure, 8(3), 2019, pp. 7-8.

${ }^{40}$ KIM, WHITFORD and ARCODIA, Development of..., pp. 422-435; DOGANER, Sedef and DUPONT, William. Accelerating cultural heritage tourism in San Antonio: A community-based tourism development proposal for the missions historic district. In: International Journal of Sustainable Development and Planning, 10(1), 2015, pp. 1-19. ${ }^{41}$ DORSON, Richard M. Folklore and fakelore: essays toward a discipline of folk studies. Cambridge: Harvard University Press, 1976, p. 5.

${ }^{42}$ BERNAU, Friedrich. Der Böhmerwald. Prag: Druck und Verlag von J. Otto in Prag, 1888, p. 103; BLAU, Josef. Böhmerwälder Hausindustrie und Volkskunst. Prag: J. G. Calvesche k. u. k. Hof und Universitats Buchhandlung, 1917, pp. 66-79.

${ }^{43}$ Voroplavba, accessed May $7^{\text {st }}, 2021$, http://voroplavba.cz
} 


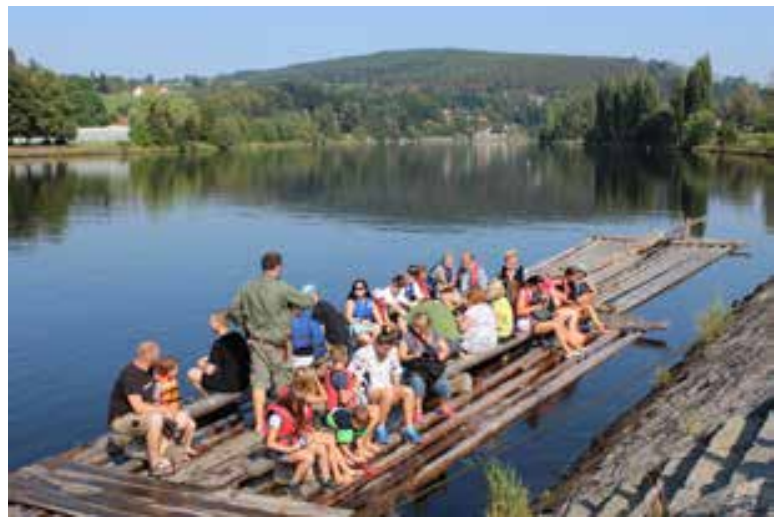

Fig. 6: Timber rafting on the Vltava River. 2020. Photo: author. mentioned in the Czech List of Intangible Elements of Traditional Folk Culture, having been added in 2017 (Fig. 6). One of the reasons this phenomenon is under national protection is that the timber rafting tradition, while no longer essential for people's livelihoods, still carries important knowledge about the technologies used to make the original rafts and helps preserve navigation folk knowledge. ${ }^{44}$ Responsibility for increasing the visibility of timber rafting currently falls to the International Association of Timber Raftsmen, which consists of 38 national associations. ${ }^{45}$ Timber rafting appears on various other Central European countries' national lists. Germany lists timber rafting generally, ${ }^{46}$ while Austria specifies "knowledge of timber rafting on the Upper Drau", ${ }^{47}$ and Poland highlights "rafting traditions in Ulanów". ${ }^{48}$ The National Register of Intangible Cultural Heritage of Slovenia does not feature timber rafting, but does mention other traditional methods of transport, specifically, making pletna boats and using them on Lake Bled, cable ferrying, and making drevak boats. ${ }^{49}$ These examples can all still be considered an unchanged form of cultural heritage.

In addition, in 2021, six European states - Austria, Czechia, Germany, Latvia, Poland and Spain - jointly submitted a transnational nomination for timber rafting to be added to the UNESCO Representative List of the Intangible Cultural Heritage of Humanity. ${ }^{50}$

These examples clearly show the importance of identifying cultural heritage phenomena and raising their visibility by forming associations, organising cultural and social events for association members and the public, and raising public awareness by including these practices on lists of protected cultural heritage.

Although the examples mentioned above may lead to timber rafting being assessed as an essentially folkloristic phenomenon, repackaged for tourists, the possibility that some of its original functions will be restored in the future cannot be definitively dismissed. For example, wood is currently experiencing something of a renaissance in contemporary construction prac-

\footnotetext{
${ }^{44}$ Národní ústav lidové kultury - Tradiční vorařství na řece Vltavě, accessed March 4, 2020, http://www.nulk. cz/2018/10/04/tradice-vorarstvi-na-rece-vltave

${ }^{45}$ International Association of Timber-Raftsmen, accessed March 4st 2020 , https://raftsmen.org

${ }^{46}$ Nationwide Inventory of Intangible Cultural Heritage - Timber Rafting, accessed March 4, 2020, https://www. unesco.de/en/timber-rafting

${ }^{47}$ Intangible Cultural Heritage - Practices, Knowledge, Craftsmanship, accessed March 4, 2020, https://www.unesco.at/en/culture/intangible-cultural-heritage/austrian-inventory/detail-1/article/knowledge-of-timber-rafting-onthe-upper-drava

${ }^{48}$ SADOWSKA-MAZUR, Katarzyna and WLODARCZYK, Julia (eds). Polish Intangible Cultural Heritage List. Warszawa: Narodowy Instytut Dziedzictwa, 2016, pp. 10-11.

${ }^{49}$ Koordinator varstva nesnovne kulturne dediščine, accessed March 4, 2020, http://www.nesnovnadediscina.si/en/ register-of-intangible-cultural-heritage

${ }^{50}$ Radio Prague International, accessed March 18, 2021, http:/ /english.radio.cz/czechs-submit-joint-unesco-bid-timber-rafting-tradition- 8712338
} 


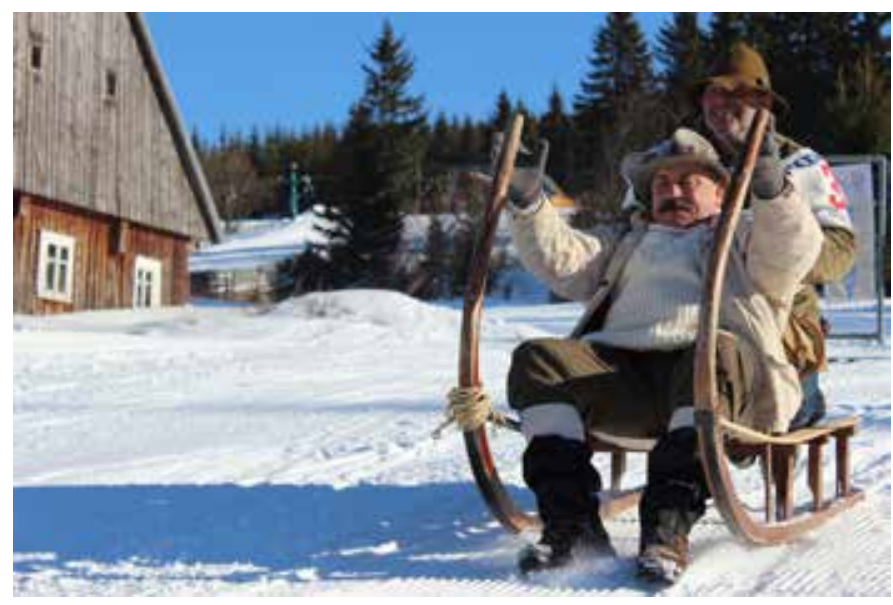

Fig. 7: Races on rohackey sledges in the Krkonoše mountain range. 2017. Photo: author. troughs, such as the Rakytovo water channel near Dolný Harmanec in Slovakia. ${ }^{52}$ Porters' races are also held occasionally in Krkonoše, in the Czech Republic where, unlike Slovakia, the profession of porter has already entered the realm of folklorism. ${ }^{53}$

These examples loosely connect to the above-mentioned notion that cultural heritage can be preserved when it is economically viable for the community. ${ }^{54}$ While this view can be accepted, other factors relevant to the viability of cultural heritage, such as entertainment or interest in history, should not be forgotten. Folklorism can therefore also be seen as "a new awareness that seeks to find novel ways to communicate with the past". ${ }^{55}$ Based on the examples above, I believe it is useful to distinguish two approaches to maintaining the viability of cultural heritage through folklorism. The first type involves merely the reconstruction of traditional phenomena and remembrance of the past. The second type of folklorism imbues traditional phenomena with a completely new function, such as entertainment (e.g., sledge races), or else provides a new form of livelihood, such as charging tourists for raft rides.

\section{Extinct forms}

The case of transport heritage demonstrates that many traditional technologies which were passed down through generations disappeared as a result of increasing mechanisation, leaving only rare instances preserved by a limited number of individuals (for example, see Fig. 8).

\footnotetext{
${ }^{51}$ MAY, Sarah. Holz. Ökonomien, Politiken, kulturwissenschaftliche Potenziale. Zeitschrift fur Volkskunde, 114(2), 2018 , p. 247.

${ }^{52}$ JUNEK, Jiří, FIALOVÁ, Jitka and KUBÍČKOVÁ, Hana. Reconstruction of the unique water trough at Harmanec as the example of the attractiveness. In: FIALOVÁ, Jitka and PERNICOVÁ, Dana (eds). Public recreation and landscape protection - with man hand in hand! 2015 Conference Proceeding. Brno: Czech Society of Landscape Engineers and Department of Landscape Management of Faculty of Forestry and Wood Technology of Mendel University in Brno, 2015, pp. 201-204.

${ }^{53}$ Interview with H. H. (1933), porter, January 24, 2011.

${ }^{54}$ OLALERE, Intangible cultural heritage..., pp. 7-8.

${ }_{55}^{5}$ NURYANTI, Wiendu. Heritage and postmodern tourism. In: Annals of Tourism Research, 23(2), 1996, p. 250; ISTENIČ, Texts and..., p. 51.
} 


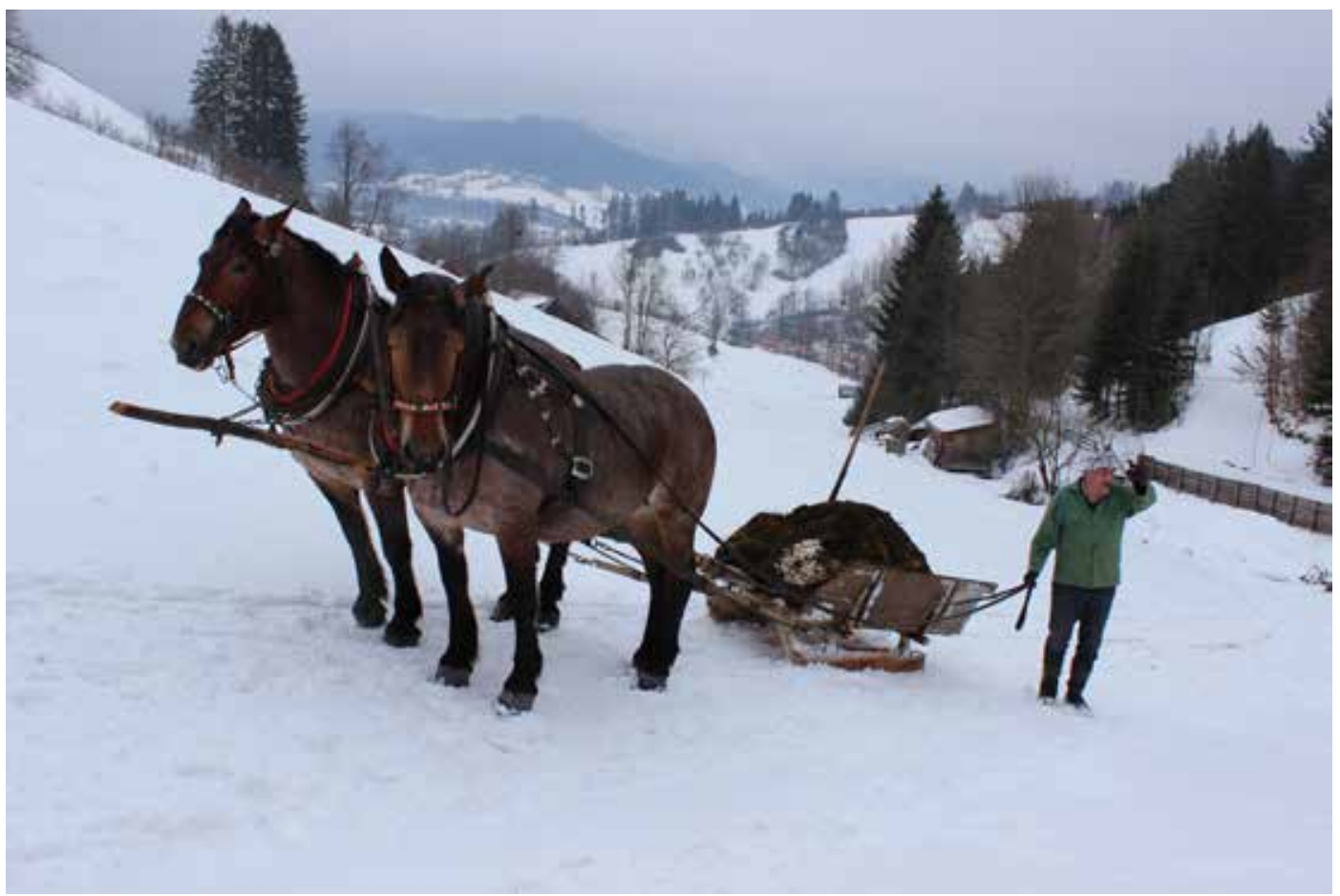

Fig. 8: Transporting manure on a horse-drawn sledge in the Novy Hrozenkov area. 2019. Photo: author.

After 1945, as a consequence of water reservoir construction, timber rafting for economic purposes disappeared from Czech and Slovak rivers. ${ }^{56}$ Other forms of transport, such as simple skids, sledges or classic wooden wagons, began to disappear in their original form in the former Czechoslovakia in the mid-twentieth century due to the development of more advanced technologies. Nevertheless, in the second half of the 20th century, traditional transport in its original form and purpose could still be found in certain areas. ${ }^{57}$ For example, in the Krkonoše Mountains, the highest mountain range in the Czech Republic, logs and timber were routinely transported on sledges in the 1960s. ${ }^{58}$ Similarly, in Slovakia in the 1960s, ethnographers documented timber sledging ${ }^{59}$ and wooden wagons; these were used still in the 1990s, for example, by Carpathian herdsmen on the Slovak-Polish border. ${ }^{60}$ In these cases, we cannot speak of the efforts to preserve the viability of cultural heritage, but rather efforts to preserve its memory through information collected during salvage ethnographic research and presented in academic publications. Researchers were fortunate that, at the time when Europe's

${ }^{56}$ SCHEUFLER, Vladimír and ŠOLC, Václav. Voroplavba na jihočeských tocích. Praha: Ústav pro etnografii a folkloristiku CAV, 1970, p. 43; The transportation of timber in a bound or unbound state by water was stricken by the first wave of decline in traditional transport in some places in the Czech and Slovak lands at the end of the nineteenth century; JEŘÁBEK, Richard. Karpatské vorařství v 19. století. Praha: Státní pedagogické nakladatelství, 1961, pp. 19, 96.

${ }^{57}$ BARAN, Transport in..., pp. 57-89.

${ }^{58}$ LYSÝ, František. Lesní tě̌̌̌ba. Praha: Státní zemědělské nakladatelství, 1963, pp. 327-328.

${ }^{59}$ PODOLÁK, Ján. Zimná doprava sena z horských lúk na západnej strane Vel'kej Fatry. In: Slovenský národopis, 10(4), 1962, pp. 565-574; UHRÍKOVÁ, Tatiana. Tradičné spôsoby dopravy dreva na dolnej Orave. In: Slovenský národopis, 18(4), 1970, pp. 627-639.

${ }^{60}$ KOCÓJ, Ewa. Powroty do tematów pasterskich. Zwyczaje i wierzenia związane z rozpoczęciem sezonu pasterskiego na pograniczu polsko-słowackim w xxi wieku. In: Etnografia Polska, 62(1-2), 2018, pp. 85-106. 
traditional transport was disappearing or changing significantly, in some places it could still be captured in its original forms. Thus, in addition to documenting cultural-historical background, the technological processes involved were also documented, including the production of various means of transport. Moreover, in many European countries, including the former Czechoslovakia, ethnography and folkloristics developed institutionally after World War II. ${ }^{61}$ Salvage ethnography was not a local matter, specific to the former Czechoslovakia or other Central-European countries, such as Poland, ${ }^{62}$ Austria $^{63}$ or Hungary. ${ }^{64}$ Traditional presentation of transport flourished all over Europe. The appeal of this sector of traditional culture in the European environment also increased with the establishment of the Ethnological Commission for the History and Development of European Agriculture during a session of the European ethnological society Société Internationale d'Ethnologie et de Folklore (SIEF) in Prague in $1966 .{ }^{65}$

\section{Change of transport terminology}

One of the ways to maintain the viability of traditional transport and thereby preserve them is through museum protection and registration on local or international heritage lists. The problem is how to define what is valuable and should be protected. A concrete step towards protecting intangible cultural artefacts was taken by UNESCO in 1989, with its Recommendation on the Safeguarding of Traditional Culture and Folklore. ${ }^{66}$ This document, as the title implies, still works with the concepts of 'tradition' and 'folklore', which we also encounter in the transport sector. European researchers have commonly worked with the term 'traditional transport' in the past ${ }^{67}$ and it is still used, ${ }^{68}$ although the concept of 'tradition' is subject to critical discourse in the academic environment. Discussions continue regarding its artificial construction, and further questions persist, such as when tradition ceased being a part of lifestyle and became a part of national, political and economic strategies. ${ }^{69}$ However, some European researchers oppose this view, suggesting that it is not always precisely correct to talk about inventing tradition, but rather about revitalising it. ${ }^{70}$ Furthermore, in regard to different forms of transport or even clothing and footwear, only the materials used were changed, while their function remained

\footnotetext{
${ }^{61}$ SMRČKA, Aleš. Etnografický výzkum tradiční dopravy v českých a slovenských zemích - historie, současný stav a perspektivy. In: Slovensky narodopis-Slovak Ethnology, 65(1), 2017, p. 10.

${ }^{62}$ GAJEK, Kwestionariusz nr. 5...

${ }^{63}$ BOCKHORN, Bäuerliche Fahrzeuge...

${ }^{64}$ PALÁDI-KOVÁCS, Einige Bemerkungen..., pp. 409-426.

${ }^{65}$ JACOBEIT, Wolfgang. Ziele und Aufgaben der ethnologischen Kommission für Geschichte und Entwicklung der europäischen Landwirtschaf. In: Volkskunde, 68, 1967, pp. 3-11.

${ }^{66}$ VECCO, Marilena. A definition of cultural heritage: From the tangible to the intangible. In: Journal of Cultural Heritage, 11(3), 2010, p. 323.

${ }^{67}$ MARINOV, Vasil. Traditionelle Transportmittel in Bulgarien. In: FENTON, Alexander, Podolák, Ján and Rasmussen, Holger (eds). Land Transport in Europe. Copenhagen: Nationalmuseet, 1973, pp. 347-394; PARÍKOVÁ, Návod na...; UHRÍKOVÁ, Tatiana. Tradičné spôsoby dopravy dreva na dolnej Orave. In: Slovenský národopis, 18(4), 1970, pp. 627-639.

${ }^{68}$ KLODNICKI, Zygmunt. Transport i komunikacja w Karpatach Północnych. In: KłODNICKI, Zygmunt, PIEŃCZAK, Agnieszka and STOLIČNÁ, Rastislava (eds). Polska - Stowacja. Pogranicze kulturowe i etniczne. Archiwum Etnograficzne 49. Wrocław-Cieszyn: Polskie Towarzystwo Ludoznawcze 2009, pp. 117-134; NOVÁKOVÁ, Tradičné spôsoby..., pp. 55-64; SMRČKA, Etnografický výzkum..., p. 7-25.

${ }^{69}$ KULIGOWSKI, Waldemar. On new meanings of tradition. Globalization, politics and questions for anthropology. In: Cesky lid, 101(3), 2014, p. 323.

${ }^{70}$ KOCÓJ, Powroty do tematów..., p. 86.
} 
the same. ${ }^{71}$ Even the concept of 'folklore' is not foreign to transport, as can be seen in the European academic environment, where the term "folk transport" 72 is sometimes applied. The concept of "folk" itself is widely used in many European countries, as are its multiple equivalents, such as "popular culture". The concept has thus gained different meanings in different countries. ${ }^{73}$ As a result of this terminological ambiguity, divergent connotations and lack of consensus on the meaning of the above-mentioned terms, which are still applied in the humanities today, the question arises as to what exactly should be protected as traditional transport (and traditional elements in other sectors), what it should be called, and how it should be presented and publicised. All these questions fed into the creation of the relatively new concept of 'intangible cultural heritage'. ${ }^{74}$

\section{Conclusion}

It is clear that while cultural heritage can serve as a calculated political and economic tool, it still forms a natural part of current lifestyles. Traditional transport is a representative example of this. Nowdays it exists in various forms, especially in unchanged forms (e.g. horse logging, mountain porters), which may disappear as technologies develop, or may be reimagined along the lines of folklorism (e.g. raft rides for tourists, horse and sledge races).

The basic requirement for preserving often unique phenomena of traditional culture is to maintain their function, either for entertainment or as a means of living. Cultural elements should be open to change which can help them retain their significance. ${ }^{75}$ However, in times when society is experiencing great pressure from relentless modernisation, commercialisation, and global market forces, this may not suffice. In my opinion, making traditional culture visible to the public may help raise awareness and can be crucially important in maintaining the viability of traditional transport in its various forms. Cultural marketing is therefore essential, and a significant part of this is achieved by adding traditional cultural phenomena to national lists or the UNESCO lists. But increasing the visibility of traditional culture may also usher in negative effects. A staged presentation of traditional transport may lead to changes in traditions and the construction of a distorted image of cultural heritage. As a result of such practices, the public often comes across fake or distorted images of traditional culture. The role of experts is to draw attention to these negative phenomena and to seek rectification.

Further, I propose distinguishing between forms of traditional transport that continue to maintain livelihoods and generate entertainment, and forms which are merely reconstructions, intended only as imitations to recall the past. ${ }^{76}$ Phenomena in unchanged form should qualify for a different type of registration than those which exist only in the form of folklorism. Even among the latter, a clear distinction should be made between a living element used, for example, in tourism, and a reconstructed tradition. Taking the example of commercial tourist rides on Slovak pltě rafts, these are not only a reconstruction but also a means of livelihood

\footnotetext{
${ }^{71}$ KONOVŠEK, Tjaša, MIKŠA, Peter and ZORN, Matija. Od cokel do gojzarjev: Gorniška obutev na Slovenskem v 19. in 20. stoletju. In: Glasnik SED, 58(1-2), 2018, p. 53.

${ }^{72}$ ANDEL, Karol and MARKUŠ, Michal. Ludový transport v strednom Zemplíne. In: Slovenský národopis, 19(3), 1971, pp. 377-412; GUNDA, Béla. Ludový transport v Žakarovciach. In: Slovenské národopis, 3(2), 1955, pp. 150-212.

${ }^{73}$ TESTA, Alessandro. From folklore to intangible cultural heritage. Observations about a problematic filiation. In: Österreicbische Zeitscbrift fur Volkskunde, 70(3-4), 2016, p. 233-235.

${ }^{74} 2003$ UNESCO Convention, accessed March 18, 2020, http://ich.unesco.org/en/convention

${ }^{75}$ CHAN, Sustainability of..., pp. 342-361.

${ }^{76}$ ISTENIČ, Texts and..., p. 51.
} 
in the twenty-first century, yet they do not appear on local lists, despite the ethnographic literature mentioning the use of rafting in Slovakia for recreational trips in the past. ${ }^{77}$ This should subsequently be reflected in the concept of intangible cultural heritage. For example, distinguishing the form of a given cultural phenomenon by adjusting its registration type would be appropriate.

Furthermore, I consider the requirement of the practitioners' identification with the cultural phenomenon - that is, the expectation they should think of it as a part of their cultural heritage - to be problematic. I learnt that far from all practitioners recognise significant and endangered cultural phenomena as cultural heritage, this being one of the important features of the definition of intangible cultural heritage in the 2003 UNESCO Convention. As a result, this may prevent valuable traditional phenomena from appearing on representative lists in the future and may even lead to their extinction.

\section{Funding}

This study was created with the help of Support for Long-Term Conceptual Development of a Research Organisation (RVO): 68378076, Institute of Ethnology of the Czech Academy of Sciences.

\section{References}

\section{Literature}

ANDEL, Karol and MARKUŠ, Michal (1971). L’udový transport v strednom Zemplíne [Folk Transport in Central Zemplin]. In: Slovenský národopis, 19(3), pp. 377-412. [In Slovakian]

BARAN, Ludvík (1973). Transport in Czechoslovakia as an Ethnographical and Social Phenomenon. In: FENTON, Alexander, Podolák, Ján and Rasmussen, Holger (eds). Land Transport in Europe. Copenhagen: Nationalmuseet, pp. 57-89. ISBN 87-480-5901-3.

BERNAU, Friedrich (1888). Der Böhmerwald [The Bohemian Forest]. Prag: Druck und Verlag von J. Otto in Prag. [In German]

BLAU, Josef (1917). Böhmerwälder Hausindustrie und Volkskunst [Bohemian Forest Home Industry and Folk Art]. Prag: J. G. Calvesche k. u. k. Hof und Universitats Buchhandlung. [In German]

BOCKHORN, Olaf (1988). Bänerliche Fahrzenge aus dem Müblviertel [Rural Vehicles from Mühlviertel]. Linz: OÖ. Musealverein - Gesellschaft für Landeskunde. [In German]

CHAN, Clare S. C. (2018). Sustainability of indigenous folk tales, music and cultural heritage through innovation. In: Journal of Cultural Heritage Management and Sustainable Development, 8(3), pp. 342-361. ISSN 2044-1266. DOI 10.1108/JCHMSD-06-2017-0044

DOGANER, Sedef and DUPONT, William (2015). Accelerating cultural heritage tourism in San Antonio: A community-based tourism development proposal for the missions historic district. In: International Journal of Sustainable Development and Planning, 10(1), pp. 1-19. ISSN 1743-7601. DOI 10.2495/SDP-V10-N1-1-19

DORSON, Richard M. (1976). Folklore and fakelore: essays toward a discipline of folk studies. Cambridge: Harvard University Press. ISBN 0-674-30715-1.

${ }^{77}$ HUSKA, Miroslav A. Slovenski pltnici. Martin: Osveta, 1972, p. 56. 
DOVČ, Peter, KAVAR, Tatjana, SÖLKNER, Hans and ACHMANN, Roland (2006). Development of the Lipizzan horse breed. In: Reproduction in Domestic Animals, 41(4), pp. 280-285. ISSN 0936-6768. DOI 10.1111/j.1439-0531.2006.00726.x

DRÁPALA, Daniel (2007). Doprava [Transport]. In: BROUČEK, Stanislav and JEŘÁBEK, Richard (eds.). Lidová kultura. Národopisná encyklopedie Cech, Moravy a Slezskea. 2. svazek. [Folk culture. Ethnographic encyclopedia of Bohemia, Moravia and Silesia. Volume 2]. Praha: Mladá fronta, 2007, pp. 449-451. ISBN 978-80-204-1712-1. [In Czech]

DROŻDŻ, Anna (2018). Transport i komunikacja lądowa w materiałach źródłowych i publikacjach Polskiego Atlasu Etnograficznego - stan obecny i nowe perspektywy [Transport and Overland Communication in Source Materials and Publications of Polish Ethnographic Atlas - current state and new perspective]. In: Narodopisny vestnik, 77(1), pp. 5-24. ISSN 1211-8117. [In Polish]

FENTON, Alexander, PODOLÁK, Ján and RASMUSSEN, Holger (eds.) (1973). Land Transport in Europe. Copenhagen: Nationalmuseet. ISBN 87-480-5901-3.

FICSOR, Csilla and MALATINSZKY, Ákos (2014). A lovas közelítés, mint természetkímélő anyagmozgatási módszer helyzete a hazai erdőterületeken [The state of horse logging, a sustainable timber transportation method in Hungarian forests]. In: Journal of Landscape Ecology, 12(1), pp. 127-135. ISSN 1589-4673. [In Hungarian]

GAJEK, Józef (ed.) (1960). Kwestionariusz nr. 5: Transport i komunikacja ladowa [Land transport and ways]. Wrocław: PTL. [In Polish]

GUNDA, Béla (1955). Ludový transport v Žakarovciach [Folk Transport in Žakarovce]. In: Slovenský národopis, 3(2), pp. 150-212. [In Slovakian]

HUSKA, Miroslav A. (1972). Slovenskí pltníci [Slovak raftsmen]. Martin: Osveta. [In Slovakian] ISTENIČ, Saša P. (2011). Texts and contexts of folklore. In: Traditiones, 40(3), pp. 51-73. ISSN 0352-0447. DOI 10.3986/Traditio2011400304

JACOBEIT, Wolfgang (1967). Ziele und Aufgaben der ethnologischen Kommission für Geschichte und Entwicklung der europäischen Landwirtschaf [Aims and tasks of the ethnological commission for the history and development of European agriculture]. In: Volkskunde, 68, pp. 3-11. [In German]

JEŘÁBEK, Richard (1961). Karpatské vorařství v 19. století [Carpathian timber-rafting in the 19th century]. Praha: Státní pedagogické nakladatelství. [In Czech]

JUNEK, Jiří, FIALOVÁ, Jitka and KUBÍČKOVÁ, Hana (2015). Reconstruction of the unique water trough at Harmanec as the example of the attractiveness. In: FIALOVÁ, Jitka and PERNICOVÁ, Dana (eds.). Public recreation and landscape protection - with man hand in hand! 2015 Conference Proceeding. Brno: Czech Society of Landscape Engineers and Department of Landscape Management of Faculty of Forestry and Wood Technology of Mendel University in Brno, 2015, pp. 201-204. ISBN 978-80-7509-251-9.

KADLEC, Jiř́; MATYSOVÁ, Zlata (2015). Heavy Horses in City Forests of Ostrava. In: FIALOVÁ, Jitka and PERNICOVÁ, Dana (eds.). Public recreation and landscape protection - with man hand in hand! 2015 Conference Proceeding. Brno: Czech Society of Landscape Engineers and Department of Landscape Management of Faculty of Forestry and Wood Technology of Mendel University in Brno, pp. 87-89. ISBN 978-80-7509-251-9. 
KIM, Soojung, WHITFORD Michelle M. and ARCODIA Charles V. (2019). Development of intangible cultural heritage as a sustainable tourism resource: the intangible cultural heritage. In: Journal of Heritage Tourism, 14(5-6), pp. 422-435. ISSN 1743-873X. DOI 10.1080/1743873X.2018.1561703

KLODNICKI, Zygmunt (1976). Reliktowe formy transportu nasobnego i recznego w kulturach ludowych środkowej Europy [Relict forms of body and hand transport in folk cultures of Central Europe]. Praca doktorska. Wrocław. [In Polish]

KŁODNICKI, Zygmunt (2009). Transport i komunikacja w Karpatach Północnych [Transport and communication in the Northern Carpathians]. In: KLODNICKI, Zygmunt, PIEŃCZAK, Agnieszka and Stoličná, Rastislava (eds). Polska - Stowacja. Pogranicze kulturowe $i$ etniczne. Archiwum Etnograficzne 49 [Poland - Slovakia. Cultural and Ethnic Borderland. Ethnographic Archive 49]. Wrocław-Cieszyn: Polskie Towarzystwo Ludoznawcze, pp. 117134. ISBN 978-83-87266-77-6. [n Polish]

KOCÓJ, Ewa (2018). Powroty do tematów pasterskich. Zwyczaje i wierzenia związane z rozpoczęciem sezonu pasterskiego na pograniczu polsko-słowackim w xxi wieku [Returning to Pastoralist Themes. Customs and Beliefs Connected with the Start of the Pastoral Season on the Polish-Slovak Borderland in the $21^{\text {st }}$ Century]. In: Etnografia Polska, 62(1-2), pp. 85 106. ISSN 0071-1861. [In Polish]

KONOVŠEK, Tjaša, MIKŠA, Peter and ZORN, Matija (2018). Od cokel do gojzarjev: Gorniška obutev na Slovenskem v 19. in 20. stoletju [From wooden clogs to hiking boots: Mountain footwear in the $19^{\text {th }}$ and $20^{\text {th }}$ centuries]. In: Glasnik SED, 58(1-2), p. 53-64. ISSN 0351-2908.

KULIGOWSKI, Waldemar (2014). On new meanings of tradition. Globalization, politics and questions for anthropology. In: Cesky lid, 101(3), p. 321-334. ISSN 0009-0794. [In Slovenian]

LECHNER, Eva and HÖLZL, Reinhard (2008). Tiroler Almen [Tyrolean pastures]. Innsbruck: Loewenzahn. ISBN 978-3-7066-2422-0. [In German]

LOVRENTJEV, Sonja (2015). Intangible Cultural Heritage and Tourism. In: Mediterranean Journal of Social Sciences, 6(5S1), pp. 522-526. ISSN 2039-2117. DOI 10.5901/mjss.2015. v6n5s1p522

LYSÝ, František (1963). Lesni tě̌̌ba [Forest harvesting]. Praha: Státní zemědělské nakladatelství. [In Czech]

MARINOV, Vasil (1973). Traditionelle Transportmittel in Bulgarien [Traditional means of transportation in Bulgaria]. In: FENTON, Alexander, PODOLÁK, Ján and RASMUSSEN, Holger (eds). Land Transport in Europe. Copenhagen: Nationalmuseet, pp. 347-394. ISBN 87-480-5901-3. [In German]

MAY, Sarah (2018). Holz. Ökonomien, Politiken, kulturwissenschaftliche Potenziale [Wood. Economies, Policies, cultural scientific Potentials]. Zeitschrift fur Volkskunde, 114(2), pp. 236258. ISSN 0044-3700. [In German]

NING, Wang (1999). Rethinking authenticity in tourism experience. In: Annals of Tourism Research, 26(2), pp. 349-370. ISSN 0160-7383. DOI 10.4324/9781315237749-27

NOVÁKOVÁ, Katarína (2008). Tatranski nosič [Tatra porters]. Tatranská Lomnica: I\&B. ISBN 978-80-969017-5-3. [In Slovakian]

NOVÁKOVÁ, Katarína (2011). Tradičné spôsoby prepravy detí v Európe a podoby ich súčasnej revitalizácie [Traditional ways of transporting children in Europe and forms of their current revitalization]. In: Ethnologia Europea Centralis, 10, pp. 55-64. ISSN 1210-1109. [In Slovakian] 
NOVÁKOVÁ, Katarína S. (2020). Nosenie na hlave ako archaický spôsob transportu nákladov $\mathrm{v}$ európskom priestore [Head-Carrying as an Archaic Way of Burden Transport in the European Space]. In: Národopisný věstník, 79(1), pp. 43-66. ISSN 1211-8117. [In Slovakian] NOVAKOVA, Katarina and TURINICOVA, Zuzana (2014). Sherpas in High Tatras as a Touristic Phenomenon (Analysis of a specific Alpine Profession as a European attraction). In: Internetional Conference on Economics, Education and Humanities (ICEEH'14), Bali: International Center of Economics, Humanities \& Management, 2014, pp. 192-195. ISBN 978-93-84422-01-1.

NURYANTI, Wiendu (1996). Heritage and postmodern tourism. In: Annals of Tourism Research, 23(2), pp. 249-260. ISSN 0160-7383. DOI 10.1016/0160-7383(95)00062-3

OLALERE, Folasyo E. (2019). Intangible cultural heritage as tourism product: The Malaysia experience. In: African Journal of Hospitality, Tourism and Leisure, 8(3), pp. 1-10. ISSN 2223$814 \mathrm{X}$.

PALÁDI-KOVÁCS, Attila (1971). Einige Bemerkungen über die Traggeräte der ungarischen Bauernschaft [A few remarks about the carrying devices of the Hungarian peasants]. In: SZABADFALVI, József and UJVÁRY, Zoltán (eds). Studia Ethnographica et Folkloristica in honorem Béla Gunda. Müveltségés Hagyomány XIII-XIV [Study Ethnography and Folklore in Honour of Béla Gunda. Education Tradition XIII-XIV]. Debrecen: Kossuth Lajos Tudományegyetem, pp. 409-426. [In German]

PARÍKOVÁ, Magdaléna (1979). Návod na etnografický výskum transportu a dopravy [Guidance on ethnographic research on transport]. Bratislava: Slovenská národopisná spoločnost’ pri SAV. [In Slovakian]

PETRONELA, Tudorache (2016). The importance of the intangible cultural heritage in the economy. In: Procedia Economics and Finance, 39, pp. 731-736. ISSN 2212-5671.

PETROVA, Ivanka (2018). Traditional culture and contemporary economy: Constructing cultural heritage through bread-making. In: Folklore (Estonia), 71, pp. 73-88. ISSN 14060957. DOI 10.7592/FEJF2018.71.petrova

PHILLIPS, Dan (2019). Archeology, Conservation and Enhancement. The Role of Viability in the UK Planning System. In: Historic Environment: Policy and Practice, 10(3-4), pp. 345-362. ISSN 1756-7505. DOI 10.1080/17567505.2019.1684868

PODOLÁK, Ján (1962). Zimná doprava sena z horských lúk na západnej strane Vel'kej Fatry [Winter transport of hay from mountain meadows on the west side of the Great Fatra]. In: Slovenský národopis, 10(4), pp. 565-574. [In Slovakian]

SADOWSKA-MAZUR, Katarzyna and WLODARCZYK, Julia (eds.) (2016). Polish Intangible Cultural Heritage List. Warszawa: Narodowy Instytut Dziedzictwa, 2016. ISBN 978-83-6326067-5.

SCHEUFLER, Vladimír and ŠOLC, Václav (1970). Voroplavba na jihočeskeých tocích [Timber rafting on the South Bohemian rivers]. Praha: Ústav pro etnografii a folkloristiku ČAV. [In Czech]

SLABA, Martin (2012). Splavení posledního vltavského voru - příběh jedinečného muzejního experimentu z roku 1971 [Weir of the last Vltava raft - a story of a unique museum experiment from 1971]. In: STEINOVÁ, Šárka (ed.). Z historie lesního dopravnictví [From the history of forest transport]. Praha: Národní zemědělské muzeum, Banská Bystrica: LESY Slovenskej republiky š. p., Zvolen: Lesnícke a drevárske muzeum Zvolen, pp. 171-179. ISBN 978-80-86874-41-8. [In Czech] 
SLAVKOVSKÝ, Peter (2014). S nošou za industrializáciou krajiny. Tradičné podoby dopravy na slovenskom vidieku [With a backpack behind the industrialization of the country. Traditional forms of transport in the Slovak countryside]. Bratislava: VEDA and Ústav etnológie Slovenskej akadémie vied. ISBN 978-80-224-1398-5. [In Slovakian]

SMRČKA, Aleš (2014). Die Bedeutung des Heus und sein traditioneller Transport im Riesengebirge [The importance of hay and its traditional transport in Krkonoše mountains]. In: Cesky lid, 101(1), pp.77-105. ISSN 2570-9216. [In German]

SMRČKA, Aleš (2017). Etnografický výzkum tradiční dopravy v českých a slovenských zemích - historie, současný stav a perspektivy [Ethnographic Research of Traditional Transport in Czech and Slovak Lands - History, Current State and Prospects]. In: Slovensky narodopisSlovak Ethnology, 65(1), pp. 7-25. ISSN 1335-1303. [In Czech]

ŠMELKO, Vladimír (2012). História a súčasnost chovu norika muránského typu v š. p. LESY SR [History and present breeding of murikan-type Norik in š. p. LESY SR]. In: STEINOVÁ, Šárka (ed.). Z historie lesního dopravnictví [From the history of forest transport]. Praha: Národní zemědělské muzeum, Banská Bystrica: LESY Slovenskej republiky š. p., Zvolen: Lesnícke a drevárske muzeum Zvolen, pp. 194-199. ISBN 978-80-86874-41-8. [In Slovakian]

TESTA, Alessandro (2016). From folklore to intangible cultural heritage. Observations about a problematic filiation. In: Österreichische Zeitschrift fur Volkskunde, 70(3-4), pp. 221-243. ISSN 0029-9669.

UHRÍKOVÁ, Tatiana (1970). Tradičné spôsoby dopravy dreva na dolnej Orave [Traditional methods of timber transport in the lower Orava region]. In: Slovenský národopis, 18(4), pp. 627-639. [In Slovakian]

VECCO, Marilena (2010). A definition of cultural heritage: From the tangible to the intangible. In: Journal of Cultural Heritage, 11(3), pp. 321-324. ISSN 1296-2074. DOI 10.1016/j. culher.2010.01.006

VOLANSKÁ, Lubica (ed.) (2018). Reprezentativny zoznam nehmotného kultúrneho dedičstva Slovenska, Zoznam nejlepšich spôsobov ochrany nehmotnébo kultúrneho dedičstva na Slovensku [Representative list of intangible cultural heritage of Slovakia, List of best ways to protect intangible cultural heritage in Slovakia]. Bratislava: Ministerstvo kultury Slovenskej republiky - SLUK Centrum pre tradičnú l'udovú kultúru. ISBN 978-80-970602-8-2. [In Slovakian]

\section{Respondents}

Interview with J. B. (1948), coachman, August 23, 2013.

Interview with J. G. (1957), coachman, November 5, 2019.

Interview with H. H. (1933), porter, January 24, 2011.

Interview with K. H. (1953), coachman, December 17, 2017.

Interview with P. J. (1960), coachman, July 12, 2018.

\section{Internet sources}

ICH lists - Mountain Carrying, accessed February 5, 2020, https://www.ludovakultura.sk/en/ list-ich/mountain-carrying

Immaterielles Kulturerbe: Bräuche, Wissen, Handwerkstechniken - Wissen um die Lipizzanerzucht, accessed February 6, 2020, https://www.unesco.at/kultur/immaterielleskulturerbe/oesterreichisches-verzeichnis/detail/article/wissen-um-die-lipizzanerzucht/ 
Intangible Cultural Heritage - Practices, Knowledge, Craftsmanship, accessed March 4, 2020, https://www.unesco.at/en/culture/intangible-cultural-heritage/austrian-inventory/ detail-1/article/knowledge-of-timber-rafting-on-the-upper-drava

Intangible Cultural Heritage in Hungary - Lipizzaner horse breeding in Hungary, accessed February 6, 2020, http://szellemikulturalisorokseg.hu/index0_en.php?name=en_0_lipica

International Association of Timber-Raftsmen, accessed March 4, 2020, https://raftsmen.org Koordinator varstva nesnovne kulturne dediščine, accessed March 4, 2020, http://www. nesnovnadediscina.si/en/register-of-intangible-cultural-heritage

Nationwide Inventory of Intangible Cultural Heritage - Timber Rafting, accessed March 4, 2020, https://www.unesco.de/en/timber-rafting

Národní ústav lidové kultury - Tradiční vorařství na řece Vltavě, accessed March 4, 2020, http:/ /www.nulk.cz/2018/10/04/tradice-vorarstvi-na-rece-vltave

Radio Prague International, accessed March 18, 2021, http://english.radio.cz/czechs-submitjoint-unesco-bid-timber-rafting-tradition- 8712338

Voroplavba, accessed May 7, 2021, http://voroplavba.cz

2003 UNESCO Convention, accessed March 18, 2020, http://ich.unesco.org/en/convention 